\title{
The Effect of Service Quality on Worth of Mouth Positive Intervening by Student Satisfaction and Attitude, Moderation of Student Characteristics on the Effect of Service Quality on Student Satisfaction
}

\author{
Moch. Saifudin ${ }^{1^{*}}$ \\ ${ }^{1}$ UIN Prof. KH. Saifuddin Zubri, Purwokerto
}

Corresponding Author: ${ }^{1 *}$ saifudinm725@gmail.com

Article

History:

Submit:

2021-05-20

Publish:

2021-06-14

\section{Abstract}

This research purpose to analyze affected: 1) service quality to student satisfaction, 2) service quality to student atittudes, 3) moderation of student characteristic at affected service service to student satisfaction, 4) service quality to positive Word of Mouth, 5) student satisfaction to positive Word of Mouth, dan 6) student atittudes to positive Word of Mouth, 7) The mediation of satisfaction and students atittudes on affected of quality service to positive Word of Mouth. The using data was primary data which had by questioner brought to 150 higher students of Economic and Business Islamic Faculty of State Institute for Islamic Studies Purwokerto as respondence. Then, data analized by Structural Equation Modelling (SEM). The result of research shown that: 1) Service quality had positive affected to student satisfaction, 2) Service quality had positive affected to student atittudes, 3) Student characteristic not moderated in affected service quality to student satisfaction, 4) Service quality had positive affected to positive Word of Mouth, 5) Student satisfaction had positive affected to positive Word of Mouth, and 6) Student atittudes had positive affected to positive Word of Mouth, 7) Satisfaction and students atittudes mediating of quality service affect to positive Word of Mouth. Keywords: Service Quality, Characteristic, Satisfaction, Atittudes of Higher Students, and positive Word of Mouth. 
Journal Homepage http://ijssr.net/index.php/ijssr

This is an Open Access article under the CC BY SA license

$\begin{array}{ll}\text { Published by } & \text { https://creativecommons.org/licenses/by-sa/4.0/ } \\ \text { Indonesian Academy of Social and Religious Research }\end{array}$

\section{Introduction}

College as an institution providing educational services is required to provide services that are able to create maximum satisfaction for the community who use its services. In this case, one of the important performance measures in higher education is the satisfaction felt by students related to the programs and services provided. Faculty of Islamic Economics and Business, State Institute for Islamic Studies Purwokerto, strives to provide good service quality to students so that they can compete with other higher education institutions in Purwokerto. Representative educational facilities that support learning, and computerized administration that can be accessed independently easily and quickly by students. In fact, the facility received a positive response from students. However, it needs to be investigated further, so that it can be known empirically how the influence of service quality on student satisfaction is moderated by student characteristics, and how the influence of service quality on WOM is intervened by consumer satisfaction and attitudes.

Parasuraman define service quality as a comparison between customer expectations and perceptions of the actual service received. ${ }^{1}$ The actual service consists of five dimensions, namely tangibles, reliability, responsiveness, assurance, and empathy. Furthermore, Keller explains that service quality starts from customer needs and ends at customer perception. ${ }^{2}$

The influence of service quality on consumer satisfaction has been carried out by several researchers and gave different results, such as Chong which showed that service quality had an effect on satisfaction, ${ }^{3}$ while Kundi showed that the dimensions of reliability, responsiveness and empathy had no effect on student satisfaction. ${ }^{4}$ This study is different from previous research, namely in

1 A Parasuraman, Valarie A Zeithaml, and L Berry, "SERVQUAL: A Multiple-Item Scale for Measuring Consumer Perceptions of Service Quality,” 1988 64, no. 1 (1988): 12-40.

2 Philip Kotler and Kevin Lane Keller, "Manajemen Pemasaran, Edisi Kedua Belas, Jilid 1, Terjemahan Oleh Benyamin Molan, Jakarta: Penerbit PT Indeks," 2010.

3 Pui-Yee Chong, "Internationalisation of Higher Education: Proposed Framework on International Students' Satisfaction.," Pertanika Journal of Social Sciences \& Humanities 23 (2015).

4 Ghulam Muhammad Kundi et al., "Impact of Service Quality on Customer Satisfaction in Higher Education Institutions," Industrial Engineering Letters 4, no. 3 (2014): 23-28. 
the relationship between service quality and student satisfaction moderated by student characteristics, then student satisfaction and attitudes are positioned as intervening variables in the relationship between service quality and WOM.

The development of this research is to add moderating variables to the relationship between service quality and student satisfaction. According to Huang and Yang, student characteristics can be used as moderating variables on the relationship between perceived quality variables and customer satisfaction. ${ }^{5}$ Another development of this research is to add student attitudes and WOM variables, placing student satisfaction and attitude variables as intervening variables, and WOM variables as the dependent variable (Y). Lestari shows that there is an effect of service quality on customer satisfaction, the empathy indicator has the greatest influence on customer satisfaction. ${ }^{6}$ In addition, Lestari found the influence of service quality on word of mouth and the effect of customer satisfaction on word of mouth. ${ }^{7}$

Based on the initial study above, it can be seen that the perception of service quality and perceived satisfaction varies from one student to another, Likewise, the positive attitudes and WOM carried out by them cannot be known with certainty, therefore research needs to be done. In addition, as many as 558 students certainly have different characters such as educational background (high school, vocational, or MA, both public and private), economic status, or area of origin, and these conditions may affect student satisfaction of the Faculty of Islamic Economics and Business, State Institute for Islamic Studies Purwokerto.

\section{Methods}

This study uses a quantitative approach. In accordance with the analytical tool used, namely Structural Equation Modeling (SEM), the finding of a representative number of samples according to Ferdinand (2011) is the number of indicators multiplied by 5 to 10 because the number of indicators used in this study is 26 , so the sample size is in the range $110-220$. In addition to these criteria, there are other criteria that are often used to determine the sample

5 Lily Huang, Zhilin Yang, and Gerald M Hampton, "Assessing Customer Satisfaction with NonProfit Organizations: Evidence from Higher Education," Asian Journal of Business Research 1, no. 2 (2011).

6 Anik Lestari A, "Pengaruh Kualitas Layanan Dan Harga Terhadap Word of Mouth Dengan Kepuasan Pelanggan Sebagai Variabel Intervening (Studi Pada Pengunjung Timezone Plaza Surabaya)," Buletin Ekonomi 2, no. 1 (2013): 1-26.

7 Lestari A. 
size, which is between $100-200$. Based on these two considerations, the sample size in this study was set at 150 students of State Institute for Islamic Studies Purwokerto. The sampling technique used in this research was random sampling, which was carried out by drawing lots of students who were still active in college based on the student ID number to get as many respondents as the number of research samples. The data analysis technique to test the hypothesis used in this study is the Structural Model Equation Model which is operated through the Analysis of Moment Structure (AMOS) program.

\section{Result}

\subsection{Model Conformity Test Results}

Tabel 1. Model Conformity Test Results (Goodness of Fit Test)

\begin{tabular}{llll}
\hline \multicolumn{1}{c}{ Goodness-of-fit index } & \multicolumn{1}{c}{ Result } & \multicolumn{1}{c}{ Cut of Value } & explanation \\
\hline Chi-Square & 163.904 & $<\mathrm{x} 2=189,424$ & Good \\
Significant probability & .378 & $\geq 0,05$ & Good \\
GFI $\geq$ & .918 & $\geq 0,90$ & Good \\
AGFI $\geq$ & .890 & $\geq 0,90$ & Marginal \\
CFI & .999 & $\geq 0,95$ & Good \\
TLI & .999 & $\geq 0,95$ & Good \\
CMIN/DF & 0.789 & $\leq 2,0$ & Good \\
\hline
\end{tabular}

Source: Processed data, 2017.

Further explanation of the above table is as follows:

1. The resulting Chi-Square value is 163.904. This figure is well received, because it produces $\mathrm{P}$ of 0.391 (above 0.05 ). So it can be concluded that the model in this study includes a very good fit because the probability value is greater than 0.05 . So the hypothesized model fits the data.

2. Probability. The resulting probability value is 0.378 and this value is above the cut-of value (0.05), so the model is well received. This indicates that there is no significant difference between the data covariance matrix and the estimated covariance matrix. 
3. CMIN/DF (The Minimum Sample Of Discrepancy Function Divide with Degree of Freedom) The resulting CMIN/DF value is 0.789 and this figure is less than 2.0 which indicates an acceptable fit between the model and the data. the model is well received.

4. GFI (Goodness-of-Fit Index). The resulting GFI value is 0.918 and this value is above the cut-of value (0.90). This GFI value represents the weighted proportion of the variance of the sample covariance matrix described by the estimated population matrix. The resulting value is above good fit, which means the model can be well received.

5. The resulting AGFI is 0.890 and this value is below the cut-of value (0.90). But this value is still acceptable and the model is acceptable even marginally. This AGFI value shows the weighted proportion of the variance in the sample matrix described by the estimated population matrix.

6. TLI (Tucker Lewis Index). The resulting TLI value is 0.999 and this value is above the cut-of value (0.95). The model can be received very good fit. The TLI value is an index that compares a tested model against a baseline model.

7. CFI (Comparative Fit Index). The resulting CFI value is 0.999 and this value is above the cut-of value (0.95). The model can be received very good fit. The CFI value is an index that compares a tested model against a baseline model.

8. RMSEA (The Root Mean Square Error of Approximation). The resulting RMSEA value is 0.014 and this value is less than 0.08 . The model can be received very good fit. This indicates a close fit of the model based on the degrees of freedom and it also indicates the appropriateness of the error of approximation.

\subsection{Full Model: Regression Test}

The test criteria in this study compare the $\mathrm{P}$ value with the significance level used in this study, which is $95 \%$ (0.05). If the $\mathrm{P}$ value $>0.05$, it can be concluded that there is no relationship between the two variables. 
Table 2. Full Model Causality Test Results: Regression Test

\begin{tabular}{|c|c|c|c|c|c|}
\hline & & & C.R. & $\mathbf{t}_{\text {tabel }}$ & $\mathbf{P}$ \\
\hline $\begin{array}{l}\text { Consumer } \\
\text { Satisfaction }\end{array}$ & $\leftarrow$ & Service quality & 16,606 & 1,980 & 0,000 \\
\hline Consumer Attitude & $\leftarrow$ & Service quality & 15,174 & 1,980 & 0,000 \\
\hline $\begin{array}{l}\text { Consumer } \\
\text { Satisfaction }\end{array}$ & $\leftarrow$ & $\begin{array}{l}\text { Student } \\
\text { Characteristics } 1\end{array}$ & 0,413 & 1,980 & 0,680 \\
\hline $\begin{array}{l}\text { Consumer } \\
\text { Satisfaction }\end{array}$ & $\leftarrow$ & $\begin{array}{l}\text { Student } \\
\text { Characteristics } 2\end{array}$ & $-0,855$ & 1,980 & 0,393 \\
\hline $\begin{array}{l}\text { Consumer } \\
\text { Satisfaction }\end{array}$ & $\leftarrow$ & $\begin{array}{l}\text { Student } \\
\text { Characteristics } 3\end{array}$ & 0,402 & 1,980 & 0,688 \\
\hline Word of Mouth & $\leftarrow$ & Service quality & 3,420 & 1,980 & 0,000 \\
\hline Word of Mouth & $\leftarrow$ & Consumer Attitude & 2,653 & 1,980 & ,008 \\
\hline Word of Mouth & $\leftarrow$ & $\begin{array}{l}\text { Consumer } \\
\text { Satisfaction }\end{array}$ & 2,809 & 1,980 & 0,005 \\
\hline
\end{tabular}

Source: Processed data, 2017.

This study also examines the mediation of satisfaction and attitude variables on the effect of service quality on positive WOM. Based on the results of the SEM analysis, the results obtained about the influence of service quality, student satisfaction and student attitudes directly and indirectly (mediation) as well as the total influence on positive Word of Mouth from standardized total, direct and indirect effects as follows:

Tabel 3. Total Test Results, Direct and Indirect Effects

\begin{tabular}{|c|c|c|c|c|c|}
\hline & & & $\mathrm{TE}$ & $\mathrm{DE}$ & IE \\
\hline $\begin{array}{l}\text { Consumer } \\
\text { Satisfaction }\end{array}$ & $\leftarrow$ & Service quality & & 0,961 & \\
\hline Consumer Attitude & $\leftarrow$ & Service quality & & 0,929 & \\
\hline \multirow[t]{2}{*}{ Word of Mouth } & \multirow[t]{2}{*}{$\leftarrow$} & Service quality & & 0,497 & \\
\hline & & $\begin{array}{l}\text { Consumer Attitude } \\
\text { Consumer Satisfaction }\end{array}$ & 0,991 & & 0,494 \\
\hline
\end{tabular}




\section{Explanation}

TE (Total Effect) : The total influence of service quality, satisfaction and student attitudes towards WOM is positive.

IE (Indirect Effect) : The indirect effect of service quality (by mediating student satisfaction and attitudes) on WOM is positive.

\section{Discussion}

\subsection{The Effect of Service Quality on Student Satisfaction}

The results of this study indicate conformity with the research hypothesis which states that service quality has a positive effect on student satisfaction of the Faculty of Economics and Business, State Institute for Islamic Studies Purwokerto. Students are customers or consumers for higher education institutions. Institutions should be able to guarantee student satisfaction, not only in the teaching and learning process, but also in administrative services. Administrative services, especially academic administrative services, are very important in supporting the smooth running of their studies while in college. Although some aspects have been computerized and are online, manual services are still needed, for example legalization issues, correspondence, and so on. Universities as providers of educational services for students, must place student satisfaction as one of the main goals in maintaining service quality.

Regarding the quality of service at the Faculty of Economics and Business, State Institute for Islamic Studies Purwokerto, students experience various satisfactions. Based on the answers to open questions, student satisfaction with the services of the Faculty of Economics and Business, State Institute for Islamic Studies Purwokerto has 4 gradations of satisfaction, namely very satisfied, satisfied, quite satisfied and not satisfied. Students who feel very satisfied and satisfied assess that the services provided by the campus to students have met expectations both in terms of tangible, reliability, assurance, empathy and responsiveness. Infrastructure, facilities and campus facilities and lecture halls according to student needs, administrative services provided by students are easy and fast and friendly as needed, lecturers provide lecture materials properly, friendly and easy to understand by students, and the campus and its staff are responsive to student complaints or needs. However, there are still things that need to be improved, especially those that are most highlighted are tangible problems, namely lecture 
room facilities such as air conditioners, projectors, and lamps because many are not functioning so they need to be replaced.

This study is in line with the results of research conducted by Hasan showing that the dimensions of service quality, namely tangibility, responsiveness, reliability, assurance and empathy, have a positive relationship with student satisfaction. ${ }^{8}$ The results of Trarintya's research (2011) show that service quality has a positive and significant effect on customer satisfaction.

\subsection{The Influence of Service Quality on Student Attitudes}

The results of this study indicate conformity with the research hypothesis which states that service quality has a positive effect on consumer attitudes. This means that consumers who perceive high service quality tend to have high attitudes, namely very positive feelings and behaviors.

The services provided by the Faculty of Economics and Business, State Institute for Islamic Studies Purwokerto to its students have an impact on students' attitudes towards their campus. Based on respondents' answers to openended questions, various answers were obtained, but most of them expressed feelings of being very happy or happy because the employees were good, nice and friendly in providing services, as well as the lecturers who were considered friendly, not fierce or killer, innovative, creative, and friendly appreciate students. All of these things have given a positive attitude to students, which is realized in the behavior of diligently studying, providing constructive suggestions, and completing assignments given by lecturers.

The results of this study are in line with the results of research by Amador and Widiyanto, showing that service quality has a significant positive effect on consumer attitudes. ${ }^{9}$ Research by Freymann shows the results that service quality has an effect on consumer attitudes. ${ }^{10}$ Research by Garcia show the results that the service quality of the responsiveness dimension of the campus in the form of e-learning can affect student satisfaction and perceptions. ${ }^{11}$

8 Hishamuddin Fitri Abu Hasan et al., "Service Quality and Student Satisfaction: A Case Study at Private Higher Education Institutions," International Business Research 1, no. 3 (2008): 163-75.

9 Abror Aflah Amador and Ibnu Widiyanto, "Pengaruh Kualitas Produk Dan Kualitas Pelayanan Terhadap Sikap Konsumen Dan Implikasinya Terhadap Minat Beli Ulang (Studi Kasus Pada Semerbak Coffee Tembalang Semarang)" (Fakultas Ekonomika dan Bisnis, 2012).

10 Jeffrey W von Freymann and Barry Cuffe, "Consumer Service Quality Assessments and Future Revenues in Small Businesses: A Case Study,” Services Marketing Quarterly 31, no. 4 (2010): 381-419.

11 Salvador del Barrio-García, José L Arquero, and Esteban Romero-Frías, "Personal Learning 


\subsection{Moderation of Student Characteristics on The Effect of Service Quality on Student Satisfaction.}

The results of this study indicate a discrepancy with the research hypothesis which states that student characteristics moderate the effect of service quality on customer satisfaction (students) Faculty of Economics and Business, State Institute for Islamic Studies Purwokerto. This means that student characteristics do not strengthen or weaken the effect of service quality on student satisfaction. Regional origin, school origin and socioeconomic status do not have a significant or significant impact on the assessment of the quality of services provided by the faculty and give satisfaction.

Based on research data from Faculty of Economics and Business students, the State Institute for Islamic Studies Purwokerto came from Banyumas districts, namely Purwokerto, Ajibarang, Kembaran, Cilongok and other sub-districts belonging to the Banyumas area, and from outside Banyumas such as Purbalingga, Cilacap, Ciamis, Bandung and Jakarta. They also come from different educational backgrounds, such as from private and state high schools, private and state MA, and from private and state vocational schools. Their socioeconomic status is also diverse, there are low, medium and high. However, their background or the characteristics of the students of the Faculty of Economics and Business, State Institute for Islamic Studies Purwokerto, do not cause them to have significantly different satisfaction, this means that the State Institute for Islamic Studies Purwokerto, especially the Faculty of Economics and Business treats the same to all students, there is no discrimination or domination, no favoritism towards students with certain backgrounds.

The results of this study are not in line with the opinion of Hampton where their research suggests that student characteristics can be used as moderating variables in the relationship between service quality perception variables and customer satisfaction. ${ }^{12}$ And the results of this study are also not in line with research conducted by Duong which shows the results of research that student characteristics moderate the relationship between service quality and student satisfaction. ${ }^{13}$

Environments Acceptance Model: The Role of Need for Cognition, e-Learning Satisfaction and Students' Perceptions," Journal of Educational Technology \& Society 18, no. 3 (2015): 129-41.

12 Huang, Yang, and Hampton, "Assessing Customer Satisfaction with Non-Profit Organizations: Evidence from Higher Education."

13 Duong Quang Minh, "The Factors Influencing Student Satisfaction in Vietnamese Higher Education," 2015. 


\subsection{The Influence of Service Quality on Word of Mouth is Positive}

The results of this study indicate conformity with the research hypothesis which states that service quality has a positive effect on Word of Mouth. This means that the higher the quality of service perceived by consumers, the higher the tendency to tell other people.

The results of this study are in line with the opinion expressed by Berry namely that service quality is related to consumer loyalty and positive WOM communication. ${ }^{14}$ Likewise, the opinion of Harrison and Walker is that service quality has a positive effect on WOM communication. ${ }^{15}$

The results of this study support research conducted by Chong which shows that service quality has a positive effect on WOM, namely by recommending the campus as an educational destination. ${ }^{16}$ Islamic Studies Purwokerto has a positive impact on WOM, based on open questions, the answer is that respondents do positive WOM because Faculty of Economics and Business, State Institute for Islamic Studies Purwokerto services are very good compared to other faculties. In addition, by studying at State Institute for Islamic Studies Purwokerto, you can also study religion.

\subsection{The Effect of Student Satisfaction on The Positive Word of Mouth}

The results of this study indicate conformity with the research hypothesis which states that student satisfaction has a positive effect on Word of Mouth. This means that the higher the satisfaction of students, the higher their tendency to tell other people.

In this study, when students feel high satisfaction with their faculty, they tend to do a positive word of mouth. Positive WOM of students is manifested in several ways, such as telling other people or friends that the services at the Faculty of Economics and Business, State Institute for Islamic Studies Purwokerto are very good, recommending and inviting friends to study at the Faculty of Economics and Business, State Institute for Islamic Studies Purwokerto. In addition to good

14 Parasuraman, Zeithaml, and Berry, "SERVQUAL: A Multiple-Item Scale for Measuring Consumer Perceptions of Service Quality."

15 Ajoy Datta et al., "The Political Economy of Policy-Making in Indonesia," Overseas Development Institute(ODI), London, UK,2011,https://smeru.or.id/sites/default/files/publication/politicaleconomy. pdf.

16 Chong, "Internationalisation of Higher Education: Proposed Framework on International Students' Satisfaction." 
service, the lecturers are kind and friendly, they can also deepen their religious knowledge.

The results of this study support the opinion of Laroche which states that customer satisfaction has a positive effect on WOM interest. ${ }^{17}$ The results of this study also support the results of research by Ranaweera and Prabhu and Brown which shows that customer satisfaction is positively related to WOM. ${ }^{18}$ Likewise, the results of research by Batubara which show that satisfaction has a positive and significant effect on student word of mouth). ${ }^{19}$ This study proves that satisfied students can attract prospective new students through positive word of mouth communication to friends and relatives, and may return to the State Institute for Islamic Studies Purwokerto after graduation to pursue further education.

\subsection{The Influence of Students Attitudes Towards Word Of Mouth is Positive Word of Mouth}

The results of this study indicate conformity with the research hypothesis which states that student attitudes have a positive effect on Word of Mouth. This means that the higher the student's attitude, the higher the tendency to do word of mouth.

A positive attitude encourages students to behave consistently to do a positive word of mouth on their campus. This happens because students feel that their campus services can meet their needs and expectations, so they do word of mouth (WOM). The positive attitude of students is realized not only by feeling happy, but also through behavior in the form of actions that are positive WOM behavior, namely telling and giving information to other people or friends about the advantages of their campus, even recommending and inviting friends to study at the Faculty of Economics and Business, State Institute for Islamic Studies Purwokerto.

The results of this study support the research conducted by Szymanski and Hernard, in Hampton which explains that customer satisfaction creates customer

17 Michel Laroche et al., "Modeling Consumer Satisfaction and Word-of-mouth: Restaurant Patronage in Korea," Journal of Services Marketing, 2005.

18 Tom J Brown et al., "Spreading the Word: Investigating Antecedents of Consumers' Positive Wordof-Mouth Intentions and Behaviors in a Retailing Context," Journal of the Academy of Marketing Science 33, no. 2 (2005): 123-38.

19 Aida W Batubara and Arlina Nurbaity Lubis, "Pengaruh Kualitas Pelayanan Terhadap Kepuasan Dan Word of Mouth Mahasiswa Program Studi Diploma III Administrasi Perpajakan FISIP USU,” Jurnal Ilmiah Manajemen Dan Bisnis 14, no. 2 (2015). 
behavior that can help companies create more effective communication and will form Word of Mouth (WOM). ${ }^{20}$

\subsection{Mediation of Student Satisfaction and Attitudes on The Effect of Service Quality on Positive Word of Mouth}

The results of this study indicate conformity with the research hypothesis which states that student satisfaction and attitudes mediate the effect of service quality on positive word of mouth. This means that student satisfaction and attitudes are variables that can bridge service quality and have a positive word of mouth impact.

This is indicated by the respondents' answers to open-ended questions, where they do positive WOM because they feel very satisfied, satisfied, very happy, happy with the services provided by the campus, especially in terms of employee and lecturer services. The results of this study are in line with the opinion conveyed by Swan and Oliver, namely that when consumers are satisfied, a positive WOM will be created and they will provide purchase recommendations to others. ${ }^{21}$ The quality of service felt by the campus by students will affect students' attitudes towards their campus which is expressed by the feelings and tendencies of students to behave, namely doing positive WOM.

The results of this study support the results of Lestari which shows that customer satisfaction mediates the effect of service quality and price on word of mouth by $58.2 \%{ }^{22}$ Likewise, it is supported by the results of research by Amador showing that product quality and service quality affect consumer attitudes and consumer attitudes affect repurchase interest. ${ }^{23}$

\section{Conclusion}

Based on the results of the research that has been discussed, the following conclusions as:

20 Huang, Yang, and Hampton, "Assessing Customer Satisfaction with Non-Profit Organizations: Evidence from Higher Education."

21 John E Swan and Richard L Oliver, "Postpurchase Communications by Consumers," Journal of Retailing 65, no. 4 (1989): 516.

22 Lestari A, "Pengaruh Kualitas Layanan Dan Harga Terhadap Word of Mouth Dengan Kepuasan Pelanggan Sebagai Variabel Intervening (Studi Pada Pengunjung Timezone Plaza Surabaya)."

23 Amador and Widiyanto, "Pengaruh Kualitas Produk Dan Kualitas Pelayanan Terhadap Sikap Konsumen Dan Implikasinya Terhadap Minat Beli Ulang (Studi Kasus Pada Semerbak Coffee Tembalang Semarang)." 
1) Service quality has a positive effect on student satisfaction of the Faculty of Economics and Business, State Institute for Islamic Studies, Purwokerto;

2) The quality of service has a positive effect on the attitudes of students of the Faculty of Economics and Business, State Institute for Islamic Studies, Purwokerto;

3) Student characteristics do not moderate the effect of service quality on student satisfaction of the Faculty of Economics and Business, State Institute for Islamic Studies, Purwokerto;

4) Service quality has a positive effect on positive Word of Mouth students of the Faculty of Economics and Business, State Institute for Islamic Studies. Purwokerto;

5) Student satisfaction has a positive effect on positive Word of Mouth students of the Faculty of Economics and Business, State Institute for Islamic Studies, Purwokerto;

6) Consumer attitudes (students) have a positive effect on positive Word of Mouth students of the Faculty of Economics and Business, State Institute for Islamic Studies, Purwokerto;

7) Student satisfaction and attitudes mediate the effect of service quality on positive Word of Mouth Faculty of Economics and Business, State Institute for Islamic Studies, Purwokerto.

\section{Reference}

Amador, Abror Aflah, and Ibnu Widiyanto. "Pengaruh Kualitas Produk Dan Kualitas Pelayanan Terhadap Sikap Konsumen Dan Implikasinya Terhadap Minat Beli Ulang (Studi Kasus Pada Semerbak Coffee Tembalang Semarang)." Fakultas Ekonomika dan Bisnis, 2012.

Barrio-García, Salvador del, José L Arquero, and Esteban Romero-Frías. "Personal Learning Environments Acceptance Model: The Role of Need for Cognition, e-Learning Satisfaction and Students' Perceptions." Journal of Educational Technology E' Society 18, no. 3 (2015): 129-41.

Batubara, Aida W, and Arlina Nurbaity Lubis. "Pengaruh Kualitas Pelayanan Terhadap Kepuasan Dan Word of Mouth Mahasiswa Program Studi Diploma III Administrasi Perpajakan FISIP USU.” Jurnal Ilmiah Manajemen Dan Bisnis 14, no. 2 (2015). 
Brown, Tom J, Thomas E Barry, Peter A Dacin, and Richard F Gunst. "Spreading the Word: Investigating Antecedents of Consumers' Positive Word-ofMouth Intentions and Behaviors in a Retailing Context." Journal of the Academy of Marketing Science 33, no. 2 (2005): 123-38.

Chong, Pui-Yee. "Internationalisation of Higher Education: Proposed Framework on International Students' Satisfaction." Pertanika Journal of Social Sciences E Humanities 23 (2015).

Datta, Ajoy, Harry Jones, Vita Febriany, Dan Harris, Rika Kumala Dewi, Leni Wild, and John Young. "The Political Economy of Policy-Making in Indonesia." Overseas Development Institute (ODI), London, UK, 2011. https://smeru.or.id/sites/default/files/publication/politicaleconomy.pdf.

Freymann, Jeffrey W von, and Barry Cuffe. "Consumer Service Quality Assessments and Future Revenues in Small Businesses: A Case Study." Services Marketing Quarterly 31, no. 4 (2010): 381-419.

Hasan, Hishamuddin Fitri Abu, Azleen Ilias, Rahida Abd Rahman, and Mohd Zulkeflee Abd Razak. "Service Quality and Student Satisfaction: A Case Study at Private Higher Education Institutions." International Business Research 1, no. 3 (2008): 163-75.

Huang, Lily, Zhilin Yang, and Gerald M Hampton. "Assessing Customer Satisfaction with Non-Profit Organizations: Evidence from Higher Education." Asian Journal of Business Research 1, no. 2 (2011).

Kotler, Philip, and Kevin Lane Keller. "Manajemen Pemasaran, Edisi Kedua Belas, Jilid 1, Terjemahan Oleh Benyamin Molan, Jakarta: Penerbit PT Indeks," 2010.

Kundi, Ghulam Muhammad, Muhammad Saqib Khan, QQureshi, Y Khan, and R Akhtar. "Impact of Service Quality on Customer Satisfaction in Higher Education Institutions." Industrial Engineering Letters 4, no. 3 (2014): 2328.

Laroche, Michel, Barry J Babin, Yong-Ki Lee, Eun-Ju Kim, and Mitch Griffin. "Modeling Consumer Satisfaction and Word-of-mouth: Restaurant Patronage in Korea." Journal of Services Marketing, 2005.

Lestari A, Anik. "Pengaruh Kualitas Layanan Dan Harga Terhadap Word of Mouth Dengan Kepuasan Pelanggan Sebagai Variabel Intervening (Studi Pada Pengunjung Timezone Plaza Surabaya)." Buletin Ekonomi 2, no. 1 (2013): 1-26. 
Minh, Duong Quang. "The Factors Influencing Student Satisfaction in Vietnamese Higher Education," 2015.

Parasuraman, A, Valarie A Zeithaml, and L Berry. "SERVQUAL: A MultipleItem Scale for Measuring Consumer Perceptions of Service Quality.” 1988 64, no. 1 (1988): 12-40.

Swan, John E, and Richard L Oliver. "Postpurchase Communications by Consumers.” Journal of Retailing 65, no. 4 (1989): 516. 
